Original Article

\title{
Effects of liquid extract from Plinia cauliflora fruits residues on Chinese hamsters biochemical parameters
}

\author{
Efeitos do extrato líquido de resíduos de frutos de Plinia cauliflora sobre os parâmetros \\ bioquímicos de hamsters chineses
}

\author{
Leonardo Luiz Borges $^{\mathrm{a}, \mathrm{b}^{*}}$ (D) , Frederico Severino Martins ${ }^{\mathrm{c}}$ (D), João José Franco ${ }^{\mathrm{c}}$, Elisa Flávia Luiz Cardoso Bailão ${ }^{\mathrm{d}}$ (D), \\ Wilson de Melo Cruvinel $^{\mathrm{b}}$ (D), Sérgio Akira Uyemurab (D) and Edemilson Cardoso da Conceição ${ }^{\mathrm{e}}$ (D) \\ aUniversidade Estadual de Goiás - UEG, Câmpus Central, Laboratório de Estudos Botânicos e Pesquisa de Produtos Naturais, Anápolis, GO, Brasil \\ 'Pontifícia Universidade Católica de Goiás - PUC Goiás, Escola de Ciências Médicas e da Vida, Laboratório de Produtos Naturais, Goiânia, GO, \\ Brasil \\ ‘Universidade de São Paulo - USP, Faculdade de Ciências Farmacêuticas de Ribeirão Preto, Departamento de Análises Clínicas, Toxicológicas e \\ Bromatológicas, Ribeirão Preto, SP, Brasil \\ dUniversidade Estadual de Goiás - UEG, Câmpus Central, Laboratório de Biotecnologia, Anápolis, GO, Brasil \\ 'Universidade Federal de Goiás - UFG, Faculdade de Farmácia, Goiânia, GO, Brasil
}

\begin{abstract}
Plinia cauliflora (Mart.) Kausel, popularly known as jabuticaba, is rich in polyphenols. Phenolic compounds exhibit several biological properties, which reflect on biomarkers such as biochemical parameters. In the present study, we evaluated the plasmatic levels of glucose, total cholesterol, HDL-cholesterol, triglycerides, and uric acid of Chinese hamsters fed for 45 days with a regular diet or cholesterol-enriched diet supplemented with a liquid extract obtained from $P$. cauliflora fruits residues standardized in ellagic acid and total phenolic compounds. The results showed that the concentrated extract obtained from jabuticaba residues increased the glycemia of animals fed with a regular diet and reduced the plasmatic uric acid levels of animals fed with a cholesterol-enriched diet. Since hyperuricemia is considered to be a significant risk factor of metabolic disorders and the principal pathological basis of gout, the liquid extract from $P$. cauliflora fruits residues would be a promising candidate as a novel hypouricaemic agent for further investigation.
\end{abstract}

Keywords: biochemical parameters, Cerrado, glycemia, jabuticaba, Myrciaria cauliflora, uric acid.

\begin{abstract}
Resumo
Plinia cauliflora (Mart.) Kausel, popularmente conhecida como jabuticaba, é rica em polifenois. Os compostos fenólicos apresentam diversas propriedades biológicas, que refletem em biomarcadores, como os parâmetros bioquímicos. No presente estudo, avaliamos os níveis plasmáticos de glicose, colesterol total, HDL-colesterol, triglicerídeos e ácido úrico em hamsters chineses alimentados por 45 dias com dieta regular ou dieta enriquecida com colesterol suplementada com extrato líquido obtido de resíduos de frutos de $P$. cauliflora padronizado em ácido elágico e compostos fenólicos totais. Os resultados mostraram que o extrato concentrado obtido dos resíduos de jabuticaba aumentou a glicemia dos animais alimentados com dieta regular e reduziu os níveis plasmáticos de ácido úrico dos animais alimentados com dieta rica em colesterol. Uma vez que a hiperuricemia é considerada um fator de risco significativo de distúrbios metabólicos e a principal base patológica da gota, o extrato líquido dos resíduos de frutas de $P$. cauliflora seria um candidato promissor como um novo agente hipouricêmico para investigação posterior.
\end{abstract}

Palavras-chave: parâmetros bioquímicos, Cerrado, glicemia, jabuticaba, Myrciaria cauliflora, ácido úrico.

\section{Introduction}

Jabuticaba - Plinia cauliflora (Mart.) Kausel - is a fruit that belongs to the Myrtaceae family, occurring mainly in Brazil's southeastern in some biomes and is typical of the Brazilian Cerrado. The fruits have a great nutritional and economic potential. They are consumed in natura, and various products can be obtained from them, such as liquor, jams, ice cream, and alcoholic beverages, highlighting the importance of this resource (Abe et al., 2011; Albuquerque et al., 2020; Clerici and Carvalho-Silva, 2011).

Besides, jabuticaba is popularly used to treat many diseases such as asthma, throat inflammation, and

*e-mail: leonardo.borges@ueg.br

Received: August 18, 2020 - Accepted: April 10, 2021

This is an Open Access article distributed under the terms of the Creative Commons Attribution License, which permits unrestricted use, distribution, and reproduction in any medium, provided the original work is properly cited. 
gastrointestinal and cardiovascular disturbances (Giraldi and Hanazaki, 2010; Borges et al., 2014). Jabuticaba peels present antioxidant, anti-inflammatory, and analgesic effects, reduced blood cholesterol and obesity-associated insulin resistance, improved glucose levels and lipid markers, and reduced adipose tissue inflammation, weight gain, dyslipidemia, and hepatic steatosis in animal models (Dragano et al., 2013; Araújo et al., 2014; Lenquiste et al., 2015; Batista et al., 2018; Brito et al., 2021).

When the jabuticaba fruits are processed, around 50\% of fruit mass is discarded, representing an environmental problem. Thus, the development of a method to reuse the residues obtained from this source is necessary. The application of the jabuticaba depulping residue in drying processes was previously investigated. Silva and colleagues determined the spray-drying conditions of the aqueous jabuticaba extract to obtain the powder with functional properties standardized in total anthocyanin content and phenolic compounds (Silva et al., 2014). Moreover, jabuticaba hydroalcoholic extract presented a good performance in a spray-drying process to obtain a powder standardized in ellagic acid and total phenolic compounds (Borges et al., 2015). These works showed that there is the possibility to reuse the residues of the jabuticaba in different conditions by spray-drying process standardized powders in different chemical markers.

Also, the investigations over this raw material's biological activities are important to know the potential functional properties of the jabuticaba residues (Guo et al., 2003; Soong and Barlow, 2004). According to Andrade et al. (2015), the concentrated liquid extract from jabuticaba residues presented in vitro activity to reduce the vascular tension and the blood pressure of isolated aortas from rats. This result revealed the great potential for the reuse of this raw material due to its biological properties. Therefore, the present study's objective was to evaluate the effects of concentrated liquid extract obtained from jabuticaba residues on biochemical parameters of diet-induced hypercholesterolemic Chinese hamsters.

\section{Materials and Methods}

\subsection{Plant material}

Winery Jabuticabal gently donated the residues of the P. cauliflora fruit peels at Hidrolândia, Goiás State, Brazil, in November 2011.

\subsection{Preparation of the hydroethanolic extract}

The dried and powdered blades of jabuticaba residues were exhaustively extracted using ethanol:water (45:55 v/v) as a solvent mixture. The resulted extract was filtered and evaporated under reduced pressure on a rotary evaporator at $40^{\circ} \mathrm{C}$, obtaining the concentrated liquid extract.

\subsection{Characterization of the concentrated liquid extract}

The density and $\mathrm{pH}$ of the extract were determined according to the Brazilian Pharmacopoeia V (Brasil, 2010). The total solids content was determined by a gravimetric method in a halogen lamp analyzer (MB 35; Ohaus Inc., Pine Brook, NJ), and viscosity was measured with a viscometer (Brookfield DV-III+; Brookfield Engineering Laboratories, Inc., Middleboro, MA).

\subsection{HPLC-PDA Ellagic Acid quantification (EAC)}

HPLC analysis was performed using Waters LC system (Milford, Massachusetts, USA) comprising a quaternary pump, a degasser, an autosampler, and a photodiode array detector, model 2998. Enpower 2.0 software was employed to control the equipment and the acquisition and treatment of data. Chromatographic separation was performed with a Zorbax Eclipse $\mathrm{RP}_{-} \mathrm{C}_{18}$ reverse-phase column $(250 \times 4.6 \mathrm{~mm}$, $5 \mu \mathrm{m}$ particle size). The mobile phase was methanol and water $(60: 40, \mathrm{v} / \mathrm{v})$ at a flow rate of $0.5 \mathrm{~mL} \cdot \mathrm{min}^{-1}$ at ambient temperature. The injection volume of all samples was $10 \mu \mathrm{L}$, the detection wavelength was $252 \mathrm{~nm}$, and the run time was $12 \mathrm{~min}$. The HPLC method was validated (data not shown) according to Agência Nacional de Vigilância Sanitária (ANVISA-Brazilian National Health Surveillance Agency) guidelines (Brasil, 2013).

\subsection{Total phenolic quantification}

Total phenolic content (TPC) was determined according to Hagerman and Butler (1978), adapted by Mole and Waterman (1987). Ferric chloride was added to aqueous extract solution under alkaline conditions to yield a colored complex with phenolic compounds, read at $510 \mathrm{~nm}$. Standard curves were prepared with tannic acid.

\subsection{Total flavonoid quantification}

Total flavonoid content (TFC) was determined following the method described by Rolim et al. (2005) with modifications. Sample absorbance was measured at $361 \mathrm{~nm}$. Standard curves were prepared with rutin.

\subsection{Animals and diets}

Experiments were performed on male Chinese hamsters (80-120 g) from the Centro de Experimentação Animal da Pontifícia Universidade Católica de Goiás (PUC Goiás). The animals were individually housed at $25^{\circ} \mathrm{C}$, under $12: 12 \mathrm{~h}$ light:dark cycle with free access to chow and tap water until the day of the experiment. Animal care and handling procedures followed the International Association for the Study of Pain guidelines for the use of animals in pain research (Zimmermann, 1983) and Institutional Animal Care and Use Committee-PUC GO 0013-1.

Animals were randomly in four groups ( $n=8 /$ cage). Group 1 (control): animals received a regular rodent diet (RD); Group 2: animals received a regular diet supplemented with the concentrated liquid extract (1\% liquid extract; w/w) (E-RD); Group 3: animals received a cholesterol-enriched diet (1\% cholesterol, w/w) (CD); Group 4: animals received a cholesterol-enriched diet ( $1 \%$ cholesterol, w/w) supplemented with the concentrated liquid extract ( $1 \%$ liquid extract, $w / w$ ) (E-CD). The liquid extract from jabuicaba residues was added daily directly at the animal's feed. After 45 days of feeding, the animals were anesthetized (isoflurane inhalation), and blood was 
collected by cardiac puncture into EDTA flasks. The plasma was separated by centrifugation and stored at $-70{ }^{\circ} \mathrm{C}$ for further analysis.

\subsection{Biochemical analysis}

Fasting blood glucose, total cholesterol, HDL-cholesterol, triglycerides, and uric acid were measured by enzymatic colorimetric assays using commercial kits (Labtest, Vista Alegre, MG, Brazil) according to the manufacturer's instructions.

\subsection{Statistical analysis}

Data are presented as means \pm SEM of measurements made on eight animals in each group. Comparisons between groups that receive or not the liquid extract obtained from $P$. cauliflora fruits residues were determined using t-test (RD x E-RD or CD x E-CD). The data were analyzed using the Prism 4 computer software (GraphPad, San Diego, USA). The value of $p<0.05$ was considered significant.

\section{Results and Discussion}

\subsection{Characterization of the concentrated extract}

The concentrated extract showed a density of $0.978 \mathrm{~g} / \mathrm{mL}$, a solid content of $12 \%$ (w/w), a pH of 3.23, and a viscosity of $4.28 \mathrm{mPa}$. The contents of EAc, TPc, and $\mathrm{TFC}$ relative to the total solid $(\mathrm{w} / \mathrm{w})$ mass were $0.027 \%$, $17.89 \%$, and $4.5 \%$.

\subsection{Biochemical parameters}

The concentrated liquid extract from jabuticaba residues increased the glycemia (27.5\%) of Chinese hamsters with a regular diet (Figure 1), which could be explained by the presence of molecules that arrived from the fermentation process, such as soluble sugars (Silva et al., 2008). The significant amount of low mass carbohydrates present in jabuticaba residues could be better absorbed by the animals, resulting in glycemia increase in E-RD group. Meta-analysis data pointed that humans' berry polyphenol consumption did not clearly affect biomarkers of glucose metabolism compared with placebo or no treatment. Although some studies indicate significant effects, these effects were too small to be clinically relevant (Rambaran et al., 2020).

The concentrated liquid extract from jabuticaba residues did not alter the plasmatic levels of triglycerides, total cholesterol, and HDL-cholesterol in Chinese hamsters with a regular diet or a cholesterol-enriched diet (Figures 2,3). In opposite to what was observed in this study, previous studies showed a reduction in serum cholesterol and triglycerides and an increase in HDL-cholesterol of rats and mice fed with jabuticaba peel (Lenquiste et al., 2012; Araújo et al., 2014; Brito et al., 2021; Batista et al., 2018). These advantages over serum biochemical markers could be explained by anthocyanins' presence (Kong et al., 2003), which may have been extracted during the fermentation process to obtain the jabuticaba beverage. Anthocyanins are generally extracted using alcoholic solutions (Khoo et al., 2017).
The concentrated liquid extract from jabuticaba residues reduced the plasmatic uric acid (47\%) of animals fed with a cholesterol-enriched diet (Figure 4). Uric acid is the terminal product of the purine nucleotide catabolism. The high level of uric acid in blood, hyperuricemia, may result in urate crystals deposition in joint tissues, which promotes inflammation and causes gout, a form of arthritis accompanied by intense pain. Also, hyperuricemia is probably associated with a diet rich in cholesterol and triglycerides, obesity, hypertension, metabolic syndrome, and cardiovascular disease (Carneiro et al., 2000; Chen et al., 2015; Jiang et al., 2020). So, the hyperuricemia treatment could help to reduce the morbidity and mortality of many patients.

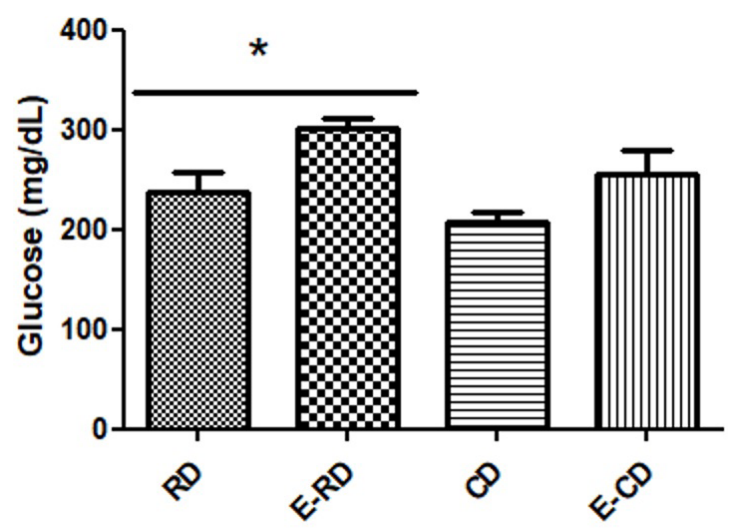

Figure 1. Blood glucose in Chinese hamsters' groups. $\mathrm{RD}=$ animals received a regular diet; $\mathrm{E}-\mathrm{RD}=$ animals received a regular diet with the concentrated liquid extract from jabuticaba residues; $\mathrm{CD}=$ animals received a cholesterol-enriched diet; $\mathrm{E}-\mathrm{CD}=$ animals received a cholesterol-enriched diet with the concentrated liquid extract from jabuticaba residues. Data are presented as mean $\pm S E$. * represents statistical differences obtained by the t-test $(\mathrm{p}<0.05)$ between groups that received or not the extract (RD $x$ E-RD or CD x E-CD).

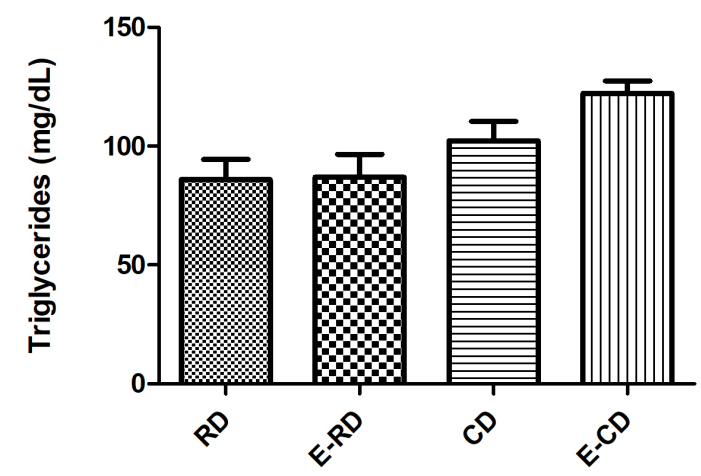

Figure 2. Plasmatic triglycerides in Chinese hamsters' groups. $\mathrm{RD}=$ animals received a regular diet; $\mathrm{E}-\mathrm{RD}=$ animals received $\mathrm{a}$ regular diet with the concentrated liquid extract from jabuticaba residues; $C D$ = animals received a cholesterol-enriched diet; $\mathrm{E}-\mathrm{CD}=$ animals received $\mathrm{a}$ cholesterol-enriched diet with the concentrated liquid extract from jabuticaba residues. Data are presented as mean \pm SE. 
A

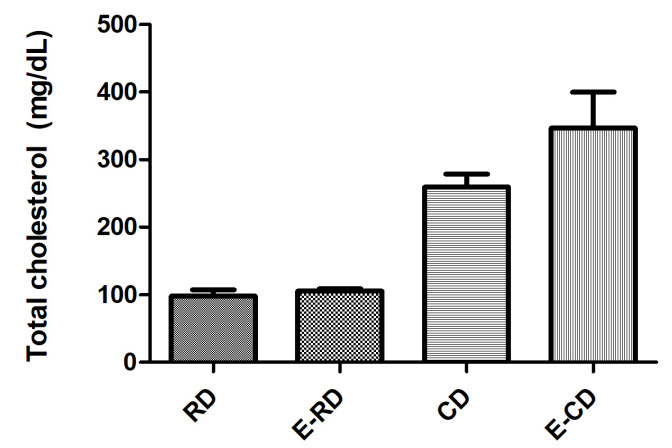

B

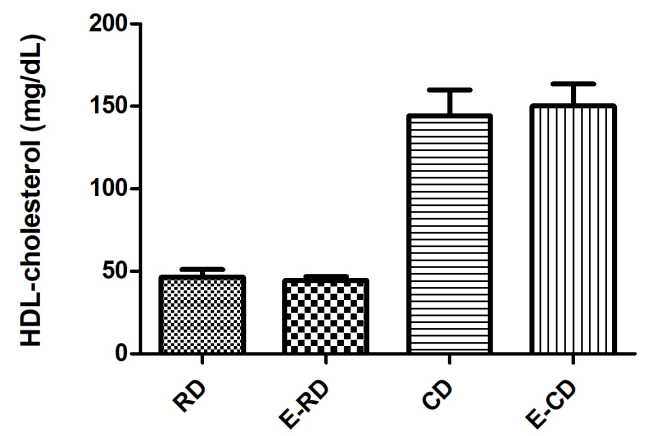

Figure 3. Plasmatic total cholesterol (A); HDL-cholesterol (B) in Chinese hamsters' groups. RD = animals received a regular diet; $\mathrm{E}-\mathrm{RD}=$ animals received a regular diet with the concentrated liquid extract from jabuticaba residues; $\mathrm{CD}=$ animals received a cholesterol-enriched diet; $\mathrm{E}-\mathrm{CD}=$ animals received a cholesterol-enriched diet with the concentrated liquid extract from jabuticaba residues. Data are presented as mean \pm SE.

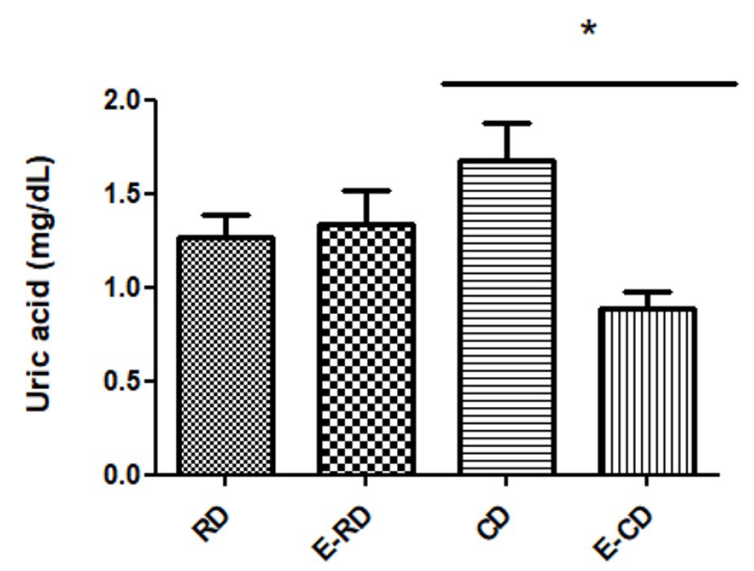

Figure 4. Plasmatic uric acid in Chinese hamsters' groups. $\mathrm{RD}=$ animals received a regular diet; $\mathrm{E}-\mathrm{RD}=$ animals received a regular diet with the concentrated liquid extract from jabuticaba residues; $C D=$ animals received a cholesterol-enriched diet; $\mathrm{E}-\mathrm{CD}=$ animals received a cholesterol-enriched diet with the concentrated liquid extract from jabuticaba residues. Data are presented as mean \pm SE. An asterisk represents statistical differences obtained by the t-test $(\mathrm{p}<0.05)$ between groups that received or not the extract (RD $x \mathrm{E}-\mathrm{RD}$ or $\mathrm{CD} \times \mathrm{E}-\mathrm{CD})$.

Currently, the clinical drugs available to treat hyperuricemia exhibit many side effects. In this sense, studies on the treatment of hyperuricemia with plantbased functional foods have received increasing attention. (Jiang et al., 2020). Oligonol ${ }^{\circledR}$, a phenolic substance produced from lychee fruit polyphenols, containing a mixture of catechin, epicatechin, proanthocyanidins, and others, lowered serum uric acid through inhibition of xanthine oxidase, a key enzyme involved in uric acid production
(Moriwaki et al., 2011). Green tea polyphenols, mainly represented by epigallocatechin-3-gallate, epigallocatechin, epicatechin-3-gallate, epicatechin, gallocatechingallate, and catechin, lowered uric acid by decreasing the uric acid production and increasing uric acid excretion (Chen et al., 2015). Moreover, flavonoids, phenolic acids, saponins, alkaloids, polysaccharides, among others, have been identified as bioactive components from plant-based functional foods that present anti- hyperuricemia activities (Jiang et al., 2020).

In summary, the results point that 45 days treatment of Chinese hamsters with the concentrated extract obtained from jabuticaba residues can alter some biochemical parameters, increasing glycemia in animals fed with a regular diet and reducing the plasmatic uric acid levels in animals fed with a cholesterol-enriched diet. Thus, even the raw material being a residue, its extract possesses biological activities over the biochemical parameters evaluated in this paper. The data presented here suggest that liquid extract from Plinia cauliflora fruits residues would be a promising candidate as a novel hypouricaemic agent for further investigation.

\section{References}

ABE, L.T., LAJOLO, F.M. and GENOVESE, M.I., 2011. Potential dietary sources of ellagic acid and other antioxidants among fruits consumed in Brazil: Jabuticaba (Myrciaria jaboticaba (Vell.) Berg). Journal of the Science of Food and Agriculture, vol. 92, no. 8, pp. 1679-1687. http://dx.doi.org/10.1002/jsfa.5531. PMid:22173652.

ALBUQUERQUE, B.R., PEREIRA, C., CALHELHA, R.C., ALVES, M.J., ABREU, R.M.V., BARROS, L., OLIVEIRA, M.B.P.P. and FERREIRA, I.C.R.F., 2020. Jabuticaba residues (Myrciaria jaboticaba (Vell.) Berg) are rich sources of valuable compounds with bioactive properties. Food Chemistry, vol. 309, pp. 125735. 
ANDRADE, D.M.L., REIS, C.F., CASTRO, P.F.S., BORGES, L.L., AMARAL, N.O., TORRES, I.M.S., REZENDE, S.G., GIL, E.S., CONCEIÇÃO, E.C., PEDRINO, G.R. and ROCHA, M.L., 2015. Vasorelaxant and hypotensive effects of Jaboticaba fruit (Myrciaria cauliflora) extract in rats. Evidence-Based Complementary and Alternative Medicine, vol. 2015, pp. 696135. http://dx.doi. org/10.1155/2015/120785. PMid:25960756.

ARAÚJO, C.R.R., ESTEVES, E.A., DESSIMONI-PINTO, N.A.V. and BATISTA, G., 2014. Myrciaria cauliflora peel flour had a hypolipidemic effect in rats fed amoderately high-fat diet. Journal of Medicinal Food, vol. 17, no. 2, pp. 262-267. http:// dx.doi.org/10.1089/jmf.2012.0256. PMid:24283277.

BATISTA, Â.G., SILVA-MAIA, J.K., MENDONÇA, M.C.P., SOARES, E.S., LIMA, G.C., BOGUSZ JUNIOR, S., CRUZ-HÖFLING, M.A. and MARÓSTICA JÚNIOR, M.R., 2018. Jaboticaba berry peel intake increases short chain fatty acids production and prevent hepatic steatosis in mice fed high-fat diet. Journal of Functional Foods, vol. 48, pp. 266-274. http://dx.doi.org/10.1016/j.jff.2018.07.020.

BORGES, L.L., CONCEIÇÃO, E.C. and SILVEIRA, D., 2014. Active compounds and medicinal properties of Myrciaria genus. Food Chemistry, vol. 153, pp. 224-233. http://dx.doi.org/10.1016/j. foodchem.2013.12.064. PMid:24491724.

BORGES, L.L., MARTINS, F.S., CONCEIÇÃO, E.C. and SILVEIRA, D., 2015. Optimization of the spray-drying process for developing jabuticaba waste powder employing response surface methodology. Journal of Food Process Engineering, vol. 40, no. 1, pp. e12276.

BRASIL. Agencia Nacional de Vigilância Sanitária. - ANVISA 2010. Farmacopeia brasileira. Agência Nacional de Vigilância Sanitária, Brasília.

BRASIL. Agencia Nacional de Vigilância Sanitária. - ANVISA, 2013 [viewed 14 April 2020]. Medicamentos fitoterápicos [online]. Agência Nacional de Vigilância Sanitária, Brasília. Available from: http://portal.anvisa.gov.br/wps/content/Anvisa+Portal/ Anvisa/Inicio/Medicamentos/Assunto+de+Interesse/ Medicamentos+fitoterapicos

BRITO, T.G.D.S., SILVA, A.P.S.A.D., CUNHA, R.X.D., FONSECA, C.S.M.D., ARAÚJO, T.F.D.S., CAMPOS, J.K.D.L., NASCIMENTO, W.M., ARAÚJO, H.D.A.D., SILVA, J.P.R.E., TAVARES, J.F., SANTOS, B.S.D. and LIMA, V.L.D.M., 2021. Anti-inflammatory, hypoglycemic, hypolipidemic, and analgesic activities of Plinia cauliflora (Mart.) Kausel (Brazilian grape) epicarp. Journal of Ethnopharmacology, vol. 268, pp. 113611. http://dx.doi.org/10.1016/j.jep.2020.113611. PMid:33242623.

CARNEIRO, J.R.I., KUSHNIR, M.C., CLEMENTE, E.L.S., BRANDÃO, M.G. and GOMES, M.B., 2000. Obesidade na adolescência: fator de risco para complicações clínico-metabólicas. Arquivos Brasileiros de Endocrinologia \& Metabologia, vol. 44, no. 5, pp. 390-396. http://dx.doi.org/10.1590/S0004-27302000000500005.

CHEN, G., TAN, M.-L., LI, K.-K., LEUNG, P.-C. and KO, C.-H., 2015. Green tea polyphenols decreases uric acid level through xanthine oxidase and renal urate transporters in hyperuricemic mice. Journal of Ethnopharmacology, vol. 175, pp. 14-20. http://dx.doi. org/10.1016/j.jep.2015.08.043. PMid:26344851.

CLERICI, M.T.P.S. and CARVALHO-SILVA, L.B., 2011. Nutritional bioactive compounds and technological aspects of minor fruits grown in Brazil. Food Research International, vol. 44, no. 7, pp. 1658-1670. http://dx.doi.org/10.1016/j.foodres.2011.04.020.

DRAGANO, N.R.V., MARQUES, A.Y.C., CINTRA, D.E.C., SOLON, C., MORARI, J., LEITE-LEGATTI, A.V., VELLOSO, L.A. and MARÓSTICAJÚNIOR, M.R., 2013. Freeze-dried jaboticaba peel powder improves insulin sensitivity in high-fat-fed mice. The British
Journal of Nutrition, vol. 110, no. 3, pp. 447-455. http://dx.doi. org/10.1017/S0007114512005090. PMid:23415177.

GIRALDI, M. and HANAZAKI, N., 2010. Use and traditional knowledge of medicinal plants at Sertão do Ribeirão, Florianópolis, Santa Catarina State, Brazil. Acta Botanica Brasílica, vol. 24, no. 2, pp. 395-406. http://dx.doi.org/10.1590/S0102-33062010000200010.

GUO, C., YANG, J., WEI, J., LI, Y., XU, J. and JIANG, Y., 2003. Antioxidant activities of peel, pulp and seed fractions of common fruits as determined by FRAP assay. Nutrition Research, vol. 23, no. 12, pp. 1719-1726. http://dx.doi.org/10.1016/j.nutres.2003.08.005.

HAGERMAN, A.E. and BUTLER, L.G., 1978. Protein precipitation method for the quantitative determination of tannins. Journal of Agricultural and Food Chemistry, vol. 26, no. 4, pp. 809-812. http://dx.doi.org/10.1021/jf60218a027.

JIANG, L.-L., GONG, X., JI, M.-Y., WANG, C.-C., WANG, J.-H. and LI, M.-H., 2020. Bioactive compounds from plant-based functional foods: a promising choice for the prevention and management of hyperuricemia. Foods, vol. 9, no. 8, pp. 973. http://dx.doi. org/10.3390/foods9080973. PMid:32717824.

KHOO, H.E., AZLAN, A., TANG, S.T. and LIM, S.M., 2017. Anthocyanidins and anthocyanins: colored pigments as food, pharmaceutical ingredients, and the potential health benefits. Food \& Nutrition Research, vol. 61, no. 1, pp. 1361779. http://dx.doi.org/10.1080/ 16546628.2017.1361779. PMid:28970777.

KONG, J.M., CHIA, L.S., GOH, N.K., CHIA, T.F. and BROUILLARD, R., 2003. Analysis and biological activities of anthocyanins. Phytochemistry, vol. 64, no. 5, pp. 923-933. http://dx.doi. org/10.1016/S0031-9422(03)00438-2. PMid:14561507.

LENQUISTE, S.A., BATISTA, Â.G., MARINELI, R.D.S., DRAGANO, N.R.V. and MARÓSTICA JUNIOR, M.R., 2012. Freeze-dried jaboticaba peel added to high-fat diet increases HDL-cholesterol and improves insulin resistance in obese rats. Food Research International, vol. 49, no. 1, pp. 153-160. http://dx.doi.org/10.1016/j. foodres.2012.07.052.

LENQUISTE, S.A., MARINELI, R.D.S., MORAES, É.A., DIONÍSIO, A.P., BRITO, E.S.D. and MARÓSTICA, M.R., 2015. Jaboticaba peel and jaboticaba peel aqueous extract shows in vitro and in vivo antioxidant properties in obesity model. Food Research International, vol. 77, pp. 162-170. http://dx.doi.org/10.1016/j. foodres.2015.07.023.

MOLE, S. and WATERMAN, P.G., 1987. A critical analysis of techniques for measuring tannins in ecological studies: I. Techniques for chemically defining tannins. Oecologia, vol. 72, no. 1, pp. 137147. http://dx.doi.org/10.1007/BF00385058. PMid:28312910.

MORIWAKI, Y., OKUDA, C., YAMAMOTO, A., KA, T., TSUTSUMI, Z., TAKAHASHI, S., YAMAMOTO, T., KITADATE, K. and WAKAME, K., 2011. Effects of Oligonol $^{\circledast}$, an oligomerized polyphenol formulated from lychee fruit, on serum concentration and urinary excretion of uric acid. Journal of Functional Foods, vol. 3, no. 1, pp. 13-16. http://dx.doi.org/10.1016/j.jff.2010.11.002.

RAMBARAN, T.F., BERGMAN, J., NORDSTRÖM, P. and NORDSTRÖM, A., 2020. Effect of berry polyphenols on glucose metabolism: a systematic review and meta-analysis of randomized controlled trials. Current Developments in Nutrition, vol. 4, no. 7, pp. nzaa100. http://dx.doi.org/10.1093/cdn/nzaa100. PMid:32666033.

ROLIM, A., MACIEL, C.P.M., KANEKO, T.M., CONSIGLIERI, V.O., SALGADO-SANTOS, I.M.N. and VELASCO, M.V.R., 2005. Validation assay for total flavonoids, as rutin equivalents, from Trichilia catigua Adr. Juss. (Meliaceae) and Ptychopetalum olacoides Bentham (Olacaceae) Commercial Extract. Journal of AOAC International, vol. 88, no. 4, pp. 1015-1019. http://dx.doi. org/10.1093/jaoac/88.4.1015. PMid:16152916. 
SILVA, M.C., SOUZA, V.B.D., THOMAZINI, M., DA SILVA, E.R., SMANIOTTO, T., CARVALHO, R.A.D., GENOVESE, M.I. and FAVARO-TRINDADE, C.S., 2014. Use of the jabuticaba (Myrciaria cauliflora) depulping residue to produce a natural pigment powder with functional properties. Lebensmittel-Wissenschaft + Technologie, vol. 55, no. 1, pp. 203-209. http://dx.doi. org/10.1016/j.lwt.2013.08.026.

SILVA, P.H.A., FARIA, F.C., TONON, B., MOTA, S.J.D. and PINTO, V.T., 2008. Avaliação da composição química de fermentados alcoólicos de jabuticaba (Myrciaria jabuticaba). Quimica Nova, vol. 31, no. 3, pp. 595-600. http://dx.doi.org/10.1590/S010040422008000300025.

SOONG, Y.Y. and BARLOW, P.J., 2004. Antioxidant activity and phenolic content of selected fruit seeds. Food Chemistry, vol. 88, no. 3, pp. 411-417. http://dx.doi.org/10.1016/j. foodchem.2004.02.003.

ZIMMERMANN, M., 1983. Ethical guidelines for investigations of experimental pain in conscious animals. Pain, vol. 16, no. 2, pp. 109-110. 